\section{LA BÚSQUEDA DE LA «BUENA» REPRESENTACIÓN: LOS DIFERENTES «USOS» DE LA PROPORCIONALIDAD}

ANA VIRGINIA PERSELLO

Ana Virginia Persello es Profesora de la Universidad Nacional de Rosario e Investigadora del Centro de Investigaciones de esa Universidad. Es también miembro del Centro de Estudios de Historia Política de la Universidad Nacional de San Martín.

e-mail: vpersello@gmail.com

\section{Resumen}

Este trabajo recupera los proyectos y debates en torno a la representación proporcional desde que se sancionó la Ley Sáenz Peña hasta que el sistema fue adoptado en Argentina en 1962. E horizonte en el que se inscribe es la cuestión de la representación, que conduce necesariamente a la pregunta acerca de qué es lo que debe o tiene que ser representado y cuya respuesta admite respuestas múltiples. El objetivo es reconstruir el camino empírico e intelectual del método del cociente, las tradiciones de pensamiento a las que se asoció su defensa y su rechazo, y finalmente los argumentos políticos que se esgrimieron en cada una de las coyunturas en que la reforma electoral formó parte de la agenda pública.
Algunas de las cuestiones planteadas en este artículo fueron propuestas en Ana Virginia Persello y Luciano de Privitellio (2009), y en: Hilda Sabato et al. (2011).

\section{Summary}

This paper recovers the projects and debates about the proportional representation from Sáenz Peña's Law sanction until the adoption of the system in Argentina in 1962. The horizon in which the topic of the representation is inscribed necessarily leads to the question of what should or must be represented, and whose response supports several answers. The aim is to reconstruct the empiric and intellectual path of the quotient method, the traditions of thoughts to which its defense and rejection were associated, and finally, the political arguments that were used in each situation in which the electoral reform was part of the public agenda. 